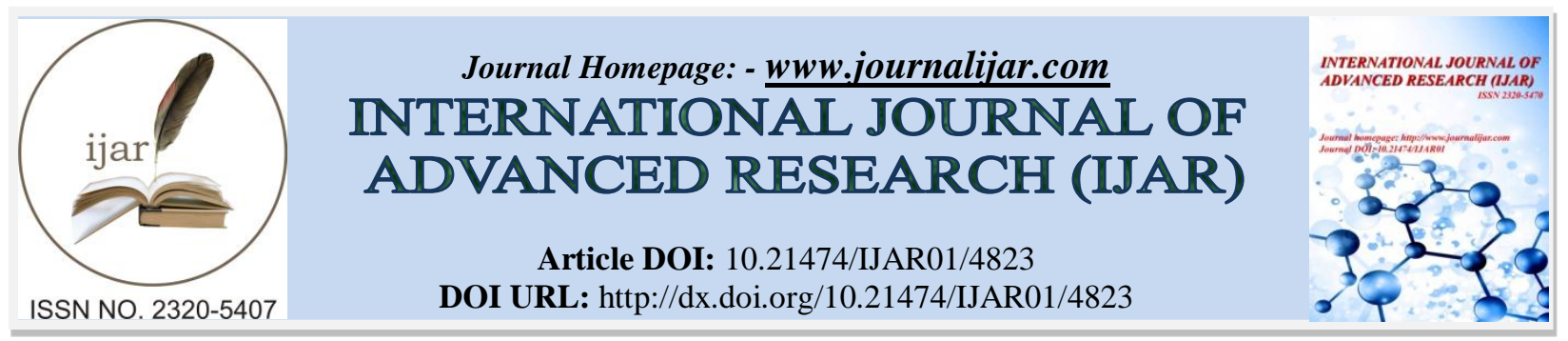

RESEARCH ARTICLE

\title{
HOMOEOPATHIC MEDICINES USED IN THE MANAGEMENT OF BASAL ROT OF ONION CAUSED BY FUSARIUM OXYSPORUM F. SP.CEPAE IN NASIK DISTRICT.
}

\author{
Jagtap J. D. and *N. S. Suryawanshi. \\ Research Laboratory, Department of Botany, K.V. Pendharkar College of Arts, Science and Commerce, Dombivli
} (E) 421203.Maharashtra India.

\section{Manuscript Info}

.........................

Manuscript History

Received: 12 May 2017

Final Accepted: 14 June 2017

Published: July 2017

Key words:-

Onion, Basal rot, Fusarium oxysporum $\mathrm{f}$.

sp. cepae, homoeopathic medicines

\section{Abstract}

Onion (Allium cepa L.) is commonly called "queen of kitchen" which is belongs to the family Alliaceae. It is grown over an area of 1173.36 ha with total production of 18928.3 MT (Source NHRDF.2014-15) in Maharashtra. Green leaves or onion bulbs is used as salad and pickling. An economic value of onion is considered to undertake to increase shelf life of post harvesting onion using homeopathic medicines. Basal rot of onion (BRO) is caused by Fusarium oxysporum f. sp. cepae the severe pathogen in field and storage condition due to this 30-40 percentage loss of onion. Objectives of this investigation is reduced the use of fungicide and increases the uses of homoeopathic medicines in controlling of basal rot disease. Total, thirty isolates were isolated from infected onions collected from various localities of Nasik district. Total nineteen homoeopathic medicines were used for the management of thiophanate methyl resistant mutant (Foc-EMS-10) of Fusarium oxysporum f. sp. cepae. Homoeopathic medicines are inhibitory against thiophanate methyl resistant mutant of $F$. oxysporum f. sp. cepae (Foc-EMS-10). Nux vomica (48.66) was highly effective against $F$. oxysporum f. sp. cepae at @ 200 Potency PCE (48.66) individually while Tuberculinum (25.66), Chelidonium majus (23.00) showed lowest PCE values and Sulphur (52.33) homoeopathic medicine @ 30 potency as compared with individual thiophanate methyl (38.66) PCE value. In case of mixture ,the Nux vomica mix with thiophanate methyl the PCE was increased up to (73.33) at @ 200 potency while Sulphur was more effective @ 30 potency, PCE (79.00) more fruitful whereas Borax (57.67) PCE was least effective against resistant mutant of $F$. oxysporum f.sp.cepae.

Copy Right, IJAR, 2017,. All rights reserved.

\section{Introduction:-}

Onion (Allium cepa L.) is one of the most important vegetable cum condiment crop of family Alliaceae, grown in over all the parts of India. Onion is used throughout the year in the form of salad or condiment or for cooking with other vegetables. It has several medicinal uses like sun strokes are known worldwide. Onion is infected by pests and fungal pathogens continue to impact on the productivity of crops and quality of crop products worldwide despite many years of research and development on improved methods for their control. Several diseases of onion caused by 
fungi were reported Basal rot of onion- Fusarium oxysporum f. sp. cepae, Pink root rot-Phoma terrestris, Black mold rot- Aspergillus niger, Black stalk rot-Stemphylium botryosum, Stemphylium blight- S. vesicarium, Blue mold -Penicillium expansum, Botrytis -Botrytis cinerea, Botrytis leaf blight- B. squamosa, Neck rot-B. allii, Damping off onion -Pythium debaryanum, Damping off onion- Rizoctonia solani, Leaf blotch-Cladosporium alli-cepa, Phytophthora neck and bulb rot- Phytophthora nicotianae, Purple blotch-Alternaria porri, Onion rot- Sclerotium rolfsii, White rot- S. cepivorum and Anthracnose- Colletotricum gleosporioides. Among these the basal rot of onion was severe. Mostly thiophanate methyl is recommended for the management of Fusarium oxysporum f. sp. cepae. But due to adverse effects of fungicides growers are keen to incorporate integrated disease management methods in the production of onions; highly effective alternatives for disease management may not be available or costeffective. There are few reports on the use of homoeopathic medicines in the management of various pathogens. Effect of homoeopathic drugs such as Lycopodium, Thuja, Arsenicum, Zincum etc. against Fusarium moniliforme, Alternaria alternata, Gloeosporium psidii, Colletotrichum gloeosporioides and Pestalotia sp. were used to control certain fruit rot pathogens. Few researchers have been reported the same aspects in controlling of plant pathogens by (Khanna and Chandra, 1989; Chandra et. al., 1981; Wilson et. al., 1991, Dahiwale and Suryawanshi 2010, Patil and Suryawanshi 2014, Suryawanshi 2015).

\section{Materials and Methods:-}

Nineteen homoeopathic medicines viz, Thuja occidentalis, Kali iodatum, Sulphur, Borax, Cina, Selenium, Lycopodium clavatum, Acidium phosphoricum, Tarentula hispana, Sambucus nigra, Rhus toxicodendron, Spongia tosta, Selenium, Nux vomica, Bryonia alba, Sanguinaria canadensis, Arnica montana, Tuberculinum and Chelidonium majus were purchased from medical store of Kalyan. It is used individually and mixtures with thiophanate methyl for the management of thiophanate methyl resistant mutant of Fusarium oxysporum f. sp. cepae (Foc-EMS-10) by food poisoning method (Nene and Thapliyal, 1982). Plates without homoeopathic medicines served as control. Both inoculated plates were incubated at $27 \pm 2^{0} \mathrm{C}$. After 10 days linear growth of Foc was measured and PCE was calculated using this formula,

$\mathrm{PCE}=\frac{\mathrm{C}-\mathrm{T}}{\mathrm{T}} \times 100$

Control, T - Mycelial Growth in Treated

Where, C - Mycelial Growth in

\section{Result and Discussion:-}

Homoeopathic medicines were used for the management of thiophanate methyl resistant mutant (Foc-EMS-10) of Fusarium oxysporum f. sp. cepae. The maximum PCE value was observed in Sulphur (52.33) homoeopathic medicine @ 30 potency was highly effective against Fusarium oxysporum f. sp. cepae used Chelidonium majus were lowest PCE (23.00) and Tuberculinum (25.66), values individually while Nux vomica (48.66) at @ of 200 potency as compared with individual thiophanate methyl (38.66) PCE value. Sulphur was mixed with thiophanate methyl PCE value (79.00) @30 potency was increased significantly as compared to individual PCE values and Nux vomica PCE value (73.33) at @ 200 potency while Chelidonium majus (53.66), Arnica montana (54.33), Tuberculinum (56.33) and Sanguinaria canadensis (56.66) @200 potency PCE was least effective against resistant mutant of $F$. oxysporum f. sp. cepae. (Table.1 and Fig.1).

Therefore, we came to conclusion and recommended the homoeopathic medicine to manage not only Fusarium but other plants pathogens. When, use of fungicide is minimum amount for the management of pathogens is a significance and more fruitful. In case of excessive use of fungicides were dangerous to crops as well as human beings while in the combination of homeopathic drugs and fungicides were less dangerous for living organisms and also crops. There are few reports on the use of homoeopathic medicines against plant pathogens. There are few researchers find the solution in the management of certain diseases on plants and results were correlated with present investigation. Khanna and Chandra (1992) investigated the control of tomato fruit rot caused by Fusarium roseus with homoeopathic drugs Kali iodatum $(149 \mathrm{CH})$ and Thuja occidentalis $(87 \mathrm{CH})$, in pre and post-harvest conditions and obtained significant results. The homoeopathic drugs Thuja and Natrum muriaticum were found to be effective on Fusarium spp. as reported by Hussain et al. (2000). Dahiwale and Suryawanshi (2010) observed that fruit rot of pomegranate caused by Alternaria alternata is one of the most important post harvest diseases. It was revealed that altogether 13 homoeopathic medicines were inhibitory against A. alternata. Out of which Arsenicum album, Argentum metallicum was highly effective fallowed by Zincum metallicum, Baptisia tinctoria, Belladonna, Tabacum, Lycopodium clavatum, Thuja occidentale, Cyanopodium, Ustilago maydis, Sepia officinale and Iris versicolar in decreasing PCE values against A. alternata. Dahiwale and Suryawanshi (2014) revealed the control of grey mould of grape caused by Botrytis cinerea using homoeopathic medicine. Patil and Suryawanshi (2014) 
noticed that the fruit rot of strawberry caused by Alternaria alternata control using homoeopathic medicines. Baviskar and Suryawanshi (2015) reported that the thirteen homoeopathic medicines were used for the management of carbendazim resistant mutant (Pe-EMS-10) of Penicillium expansum. It was seen that Sepia officinale showed significantly increased PCE (40.42) individually and Belladonna (35.85) showed lowest PCE value and all homoeopathic medicines were inhibitory against Penicillium expansum. Sepia officinale mix with carbendazim the PCE (53.25) value increased as compared to individual PCE value. The lowest PCE (35.85) was observed in Belladonna. Suryawanshi (2015) investigated that the integrated management of plant pathogens using different fungicides, plant extracts; essential oils, homoeopathic medicines and various agrochemicals use individually or in mixture with chemical or medicinal plant extracts. Investigation of fungicide resistance cases of plant pathogens in various countries is reviewed since 1980 use of fungicides, homeopathic drugs also.

Table 1:- PCE of thiophanate methyl individually and in mixture with homoeopathic medicine against resistant mutant of $F$. oxysporum f. sp cepae on PDA.

\begin{tabular}{|c|c|c|c|c|}
\hline \multirow[t]{2}{*}{ Sr. no. } & \multirow[t]{2}{*}{ Homoeopathic medicine } & \multirow[t]{2}{*}{ Potency } & \multicolumn{2}{|c|}{ Percentage Control Efficacy (PCE) } \\
\hline & & & Individual* & Mixture* \\
\hline 1. & Thuja occidentalis & 30 & 34.45 & 72.23 \\
\hline 2. & Kali iodatum & 30 & 35.56 & 68.33 \\
\hline 3. & Sulphur & 30 & 52.33 & 79.00 \\
\hline 4. & Borax & 30 & 28.88 & 57.67 \\
\hline 5. & Cina & 30 & 33.33 & 66.66 \\
\hline 6. & Selenium & 30 & 27.35 & 61.12 \\
\hline 7. & Lycopodium clavatum & 30 & 47.66 & 70.00 \\
\hline 8. & Acidium phosphoricum & 30 & 26.33 & 63.33 \\
\hline 9. & Tarentula hispana & 30 & 32.33 & 71.12 \\
\hline 10. & Sambucus nigra & 30 & 30.00 & 66.66 \\
\hline 11. & Rhus toxicodendron & 30 & 43.66 & 64.78 \\
\hline 12. & Spongia tosta & 200 & 29.33 & 57.78 \\
\hline 13. & Selenium & 200 & 34.30 & 66.68 \\
\hline 14. & Nux vomica & 200 & 48.66 & 73.33 \\
\hline 15. & Bryonia alba & 200 & 33.33 & 59.78 \\
\hline 16. & Sanguinaria Canadensis & 200 & 39.66 & 56.66 \\
\hline 17. & Arnica montana & 200 & 33.33 & 54.33 \\
\hline 18. & Tuberculinum & 200 & 25.66 & 56.33 \\
\hline 19. & Chelidonium majus & 200 & 23.00 & 53.66 \\
\hline \multirow[t]{4}{*}{20.} & Thiophanate methyl & $(60 \mu \mathrm{g} / \mathrm{ml})$ & 38.66 & -- \\
\hline & S. E. & & 1.653 & 1.802 \\
\hline & C.D. at $0.05 \%$ & & 3.386 & 7.543 \\
\hline & $0.01 \%$ & & 3.965 & 4.310 \\
\hline
\end{tabular}

* Values are the mean of three replicates 


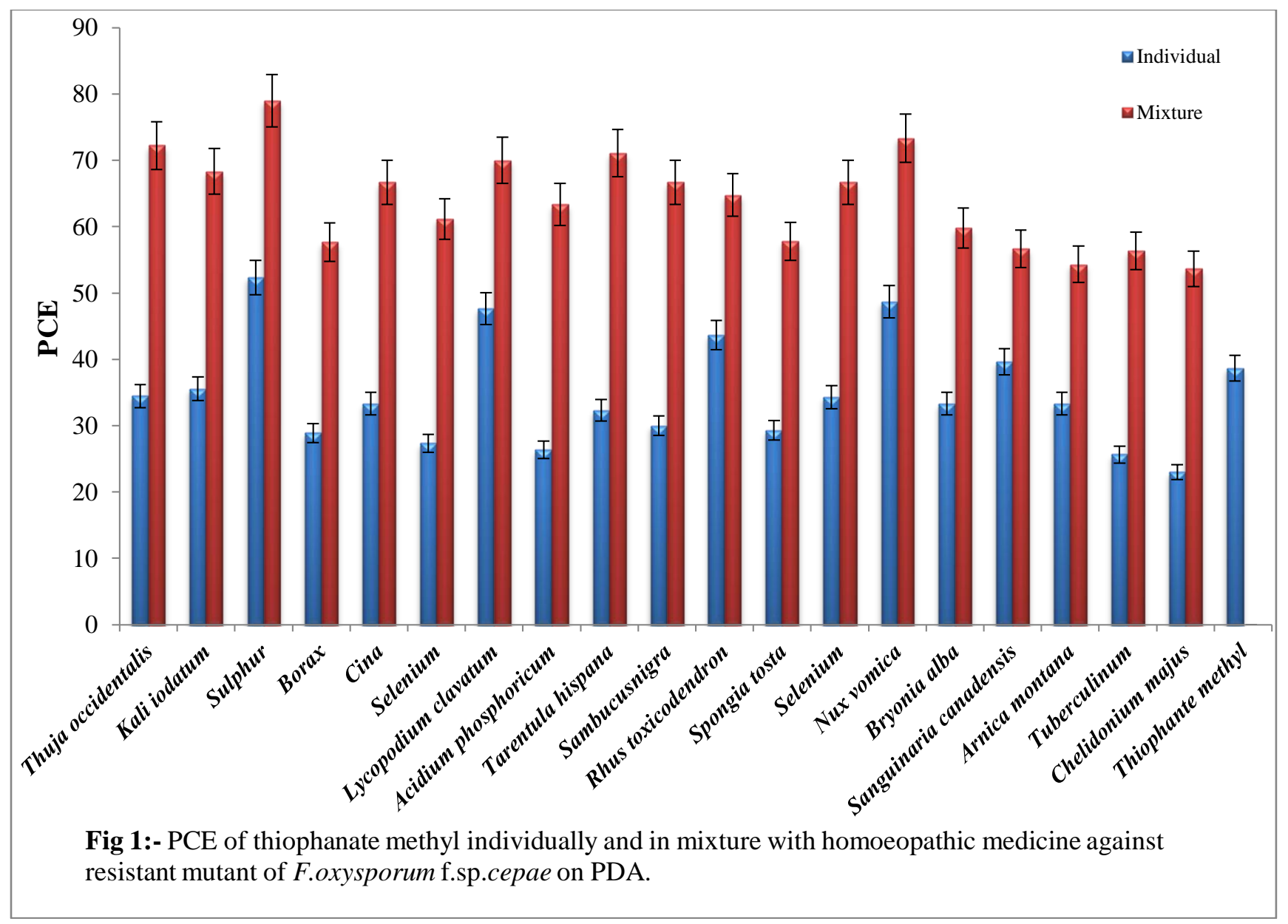

\section{Conclusion:-}

Recently, recommended homeopathic medicine for the controlling of plants, human and animal diseases. Homoeopathic medicines Nux vomica and Sulphur were inhibitory against thiophanate methyl resistant mutant of $F$. oxysporum f. sp. cepae individually and mixture with thiophanate methyl. Homeopathic medicines is simple, inexpensive and effective in controlling of Basal Rot of Onion (BRO) and maintaining the health of plants, Agriculture and environment. It is alternative for fungicides or pesticides.

\section{Acknowledgement:-}

We thankful to Emeritus Prof. L.V. Gangawane, for the valuable suggestion and motivation to do the research work and published paper in reputed journals and also thank, to Principal, Dr. A. K. Ranade, DSPM's KVP College of Arts, Science and Commerce, Dombivli, Thane for providing research facilities in the college. 


\section{References:-}

1. Baviskar R. N. and N. S. Suryawanshi (2015). Application of certain homoeopathic medicines used against fruit rot of apple caused by Penicillium expansum Link. Int. J. of Life Sciences. 3(1): 96-98.

2. Chandra H., N. K. Dubey, A. Asthana, R. D. Tripathi and S. N. Dixit (1981). Effect of some homoeopathic drugs against spore germination of some fungi. Natural Acad. Sci. Letter 4(4):161-164.

3. Dahiwale, M. A. and N. S. Suryawanshi (2010). Integrated management of carbendazim resistant Alternaria alternata using homoeopathic medicine. Bionano frontier. 3(2): 330-331.

4. Dahiwale, M. A. and N. S. Suryawanshi (2014). Grey mould of grape caused by Botrytis cinerea- control using homeopathic medicine. Fungi and Agriculture, p.3-5.

5. Hussain S. Z, Anandam R. J. and A. S. Rao (2000). Effect of different fungicides and homeopathic drugs on seed borne fungi of sunflower (Helianthus annuus L.). Indian J Plant Prot. 28(2):148-51.

6. Khanna K. K and S. Chandra (1992). Effect of homeopathic drugs on respiration of germinating fungal spores. Indian Phytopathol. 45:348-53.

7. Khanna K. K. and S. Chandra (1989). Further investigations of the control of storage rot of mango, guava and tomato fruits with homeopathic drugs. Ind. Phytopath. 13:436-440.

8. Nene Y. L. and P. N. Thapliyal (1982). Fungicide in plant disease control. Oxford and IBH Publ. Co. Pvt. New Delhi. 212-349.

9. Patil J.S. and N.S.Suryawanshi (2014). Fruit rot of strawberry caused by Alternaria alternata control using homoeopathic medicines. International Journal of Pharmaceutical Science Invention. 3(11):57-58.

10. Suryawanshi N. S. (2015). Fungicide resistance in fungal pathogens of various crops and its integrated management. Chapter-II, Published in Major Constrains and Verdict of Crop Productivity. Astral International (P) Limited, New Delhi. 21-50.

11. Wilson Charles L., Michael E. Wisniewski, Charles L. Biles, Randy McLaughlin, Edo Chalutz and Samir Droby (1991). Biological control of post harvest diseases of fruits and vegetables: alternatives to synthetic fungicides. Crop Protection. 10:172-177. 